\title{
EXTRACTION, ISOLATION AND CHARACTERIZATION OF BIOACTIVE COMPOUNDS FROM PLANTS' EXTRACTS
}

\author{
S. Sasidharan ${ }^{1, * *}$, Y. Chen ${ }^{1}$, D. Saravanan ${ }^{2}$, K.M. Sundram ${ }^{3}$, L. Yoga Latha ${ }^{1}$
}

${ }^{1}$ Institute for Research in Molecular Medicine (INFORM), Universiti Sains Malaysia, Minden 11800, Malaysia., ${ }^{2}$ Centre for Drug Research, University Science of Malaysia, 11800 Minden, Pulau Pinang. Malaysia., ${ }^{3}$ School of Pharmacy, AIMST University, Jalan Bedong-Semeling, Batu 3 1/2, Bukit Air Nasi, Bedong 08100, Kedah, Malaysia.

*E-mail: srisasidharan@yahoo.com

\begin{abstract}
Natural products from medicinal plants, either as pure compounds or as standardized extracts, provide unlimited opportunities for new drug leads because of the unmatched availability of chemical diversity. Due to an increasing demand for chemical diversity in screening programs, seeking therapeutic drugs from natural products, interest particularly in edible plants has grown throughout the world. Botanicals and herbal preparations for medicinal usage contain various types of bioactive compounds. The focus of this paper is on the analytical methodologies, which include the extraction, isolation and characterization of active ingredients in botanicals and herbal preparations. The common problems and key challenges in the extraction, isolation and characterization of active ingredients in botanicals and herbal preparations are discussed. As extraction is the most important step in the analysis of constituents present in botanicals and herbal preparations, the strengths and weaknesses of different extraction techniques are discussed. The analysis of bioactive compounds present in the plant extracts involving the applications of common phytochemical screening assays, chromatographic techniques such as HPLC and, TLC as well as nonchromatographic techniques such as immunoassay and Fourier Transform Infra Red (FTIR) are discussed.
\end{abstract}

Key words: Bioactive compound, Plant Extraction, Isolation, Herbal preparations, Natural products

\section{Introduction}

Natural products, such as plants extract, either as pure compounds or as standardized extracts, provide unlimited opportunities for new drug discoveries because of the unmatched availability of chemical diversity (Cos et al., 2006). According to the World Health Organization (WHO), more than $80 \%$ of the world's population relies on traditional medicine for their primary healthcare needs. The use of herbal medicines in Asia represents a long history of human interactions with the environment. Plants used for traditional medicine contain a wide range of substances that can be used to treat chronic as well as infectious diseases (Duraipandiyan et al., 2006). Due to the development of adverse effects and microbial resistance to the chemically synthesized drugs, men turned to ethnopharmacognosy. They found literally thousands of phytochemicals from plants as safe and broadly effective alternatives with less adverse effect. Many beneficial biological activity such as anticancer, antimicrobial, antioxidant, antidiarrheal, analgesic and wound healing activity were reported. In many cases the people claim the good benefit of certain natural or herbal products. However, clinical trials are necessary to demonstrate the effectiveness of a bioactive compound to verify this traditional claim. Clinical trials directed towards understanding the pharmacokinetics, bioavailability, efficacy, safety and drug interactions of newly developed bioactive compounds and their formulations (extracts) require a careful evaluation. Clinical trials are carefully planned to safeguard the health of the participants as well as answer specific research questions by evaluating for both immediate and long-term side effects and their outcomes are measured before the drug is widely applied to patients.

According to the World Health Organization (WHO), nearly 20,000 medicinal plants exist in 91 countries including 12 mega biodiversity countries. The premier steps to utilize the biologically active compound from plant resources are extraction, pharmacological screening, isolation and characterization of bioactive compound, toxicological evaluation and clinical evaluation. A brief summary of the general approaches in extraction, isolation and characterization of bioactive compound from plants extract can be found in Figure 1. This paper provides details in extraction, isolation and characterization of bioactive compound from plants extract with common phytochemical screening assay, chromatographic techniques, such as HPLC, and HPLC/MS and Fourier Transform Mass Spectrometry (FTMS). 


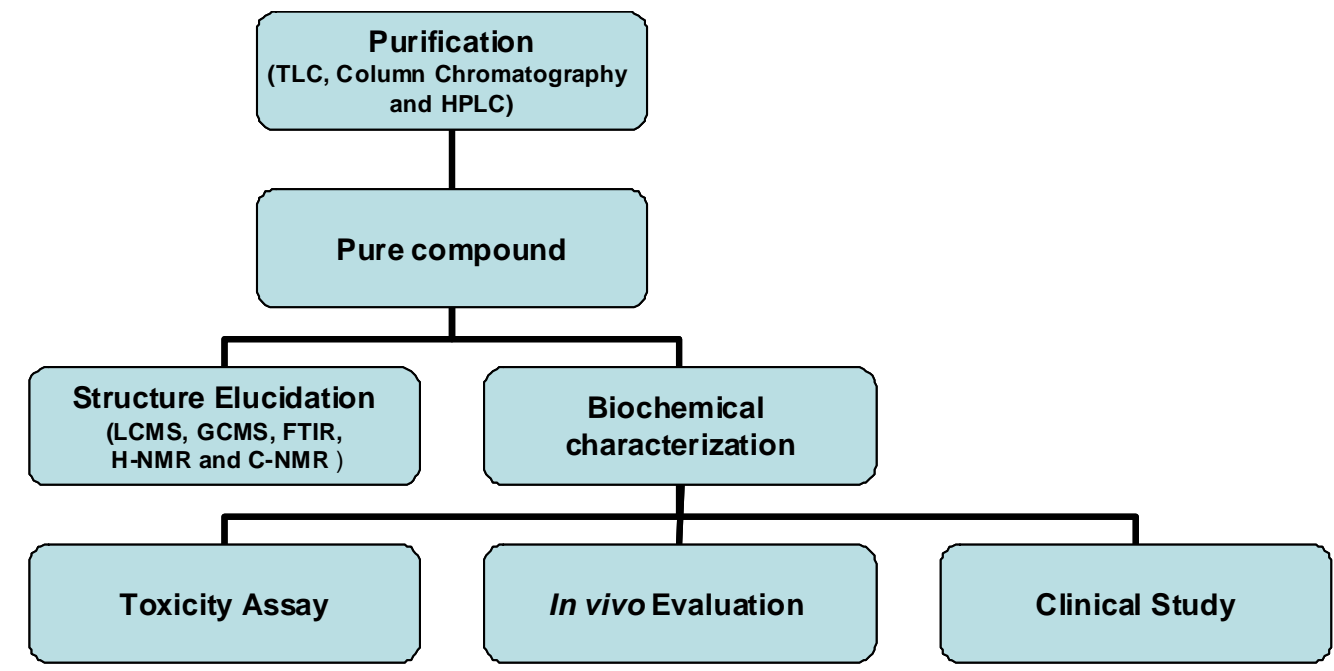

Figure 1: A brief summary of the general approaches in extraction, isolation and characterization of bioactive compound from plants extract

\section{Extraction}

Extraction is the crucial first step in the analysis of medicinal plants, because it is necessary to extract the desired chemical components from the plant materials for further separation and characterization. The basic operation included steps, such as pre-washing, drying of plant materials or freeze drying, grinding to obtain a homogenous sample and often improving the kinetics of analytic extraction and also increasing the contact of sample surface with the solvent system. Proper actions must be taken to assure that potential active constituents are not lost, distorted or destroyed during the preparation of the extract from plant samples. If the plant was selected on the basis of traditional uses (Fabricant and Farnsworth, 2001), then it is needed to prepare the extract as described by the traditional healer in order to mimic as closely as possible the traditional 'herbal' drug. The selection of solvent system largely depends on the specific nature of the bioactive compound being targeted. Different solvent systems are available to extract the bioactive compound from natural products. The extraction of hydrophilic compounds uses polar solvents such as methanol, ethanol or ethyl-acetate. For extraction of more lipophilic compounds, dichloromethane or a mixture of dichloromethane/methanol in ratio of 1:1 are used. In some instances, extraction with hexane is used to remove chlorophyll (Cos et al., 2006).

As the target compounds may be non-polar to polar and thermally labile, the suitability of the methods of extraction must be considered. Various methods, such as sonification, heating under reflux, soxhlet extraction and others are commonly used (United States Pharmacopeia and National Formulary, 2002; Pharmacopoeia of the People's Republic of China, 2000; The Japanese Pharmacopeia, 2001) for the plant samples extraction. In addition, plant extracts are also prepared by maceration or percolation of fresh green plants or dried powdered plant material in water and/or organic solvent systems. A brief summary of the experimental conditions for the various methods of extraction is shown in Table 1.

The other modern extraction techniques include solid-phase micro-extraction, supercritical-fluid extraction, pressurized-liquid extraction, microwave-assisted extraction, solid-phase extraction, and surfactant-mediated techniques, which possess certain advantages. These are the reduction in organic solvent consumption and in sample degradation, elimination of additional sample clean-up and concentration steps before chromatographic analysis, improvement in extraction efficiency, selectivity, and/ kinetics of extraction. The ease of automation for these techniques also favors their usage for the extraction of plants materials (Huie, 2002).

\section{Identification and characterization}

Due to the fact that plant extracts usually occur as a combination of various type of bioactive compounds or phytochemicals with different polarities, their separation still remains a big challenge for the process of identification and characterization of bioactive compounds. It is a common practice in isolation of these bioactive compounds that a number of different separation techniques such as TLC, column chromatography, flash chromatography, Sephadex chromatography and HPLC, should be used to obtain pure compounds. The pure compounds are then used for the determination of structure and biological activity. Beside that, non-chromatographic techniques such as immunoassay, which use monoclonal antibodies (MAbs), phytochemical screening assay, Fourier-transform infrared spectroscopy (FTIR), can also be used to obtain and facilitate the identification of the bioactive compounds. 
Table 1: A brief summary of the experimental conditions for various methods of extraction for plants material

\begin{tabular}{|c|c|c|c|}
\hline & Soxhlet extraction & Sonification & Maceration \\
\hline Common Solvents used & $\begin{array}{l}\text { Methanol, ethanol, } \\
\text { or mixture of } \\
\text { alcohol and water }\end{array}$ & $\begin{array}{l}\text { Methanol, ethanol, } \\
\text { or mixture of } \\
\text { alcohol and water }\end{array}$ & $\begin{array}{l}\text { Methanol, ethanol, } \\
\text { or mixture of } \\
\text { alcohol and water }\end{array}$ \\
\hline Temperature $\left({ }^{\circ} \mathrm{C}\right)$ & $\begin{array}{l}\text { Depending on } \\
\text { solvent used }\end{array}$ & Can be heated & Room temperature \\
\hline Pressure applied & Not applicable & Not applicable & Not applicable \\
\hline Time required & $3-18 \mathrm{hr}$ & $1 \mathrm{hr}$ & 3-4 days \\
\hline $\begin{array}{l}\text { Volume of solvent } \\
\text { required }(\mathrm{ml})\end{array}$ & $150-200$ & $50-100$ & $\begin{array}{l}\text { Depending on the } \\
\text { sample size }\end{array}$ \\
\hline Reference & $\begin{array}{l}\text { Zygmunt and Namiesnik, } \\
\text { 2003; } \\
\text { Huie, } 2002\end{array}$ & $\begin{array}{l}\text { Zygmunt and Namiesnik, } \\
\text { 2003; } \\
\text { Huie, } 2002\end{array}$ & $\begin{array}{l}\text { Phrompittayarat et al., } \\
\text { 2007; Sasidharan et al., } \\
\text { 2008; Cunha et al., 2004; } \\
\text { Woisky et al., } 1998\end{array}$ \\
\hline
\end{tabular}

\section{Chromatographic techniques}

Thin-layer chromatography (TLC) and Bio-autographic methods

TLC is a simple, quick, and inexpensive procedure that gives the researcher a quick answer as to how many components are in a mixture. TLC is also used to support the identity of a compound in a mixture when the $\mathrm{R}_{\mathrm{f}}$ of a compound is compared with the $\mathrm{R}_{\mathrm{f}}$ of a known compound. Additional tests involve the spraying of phytochemical screening reagents, which cause color changes according to the phytochemicals existing in a plants extract; or by viewing the plate under the UV light. This has also been used for confirmation of purity and identity of isolated compounds.

Bio-autography is a useful technique to determine bioactive compound with antimicrobial activity from plant extract. TLC bioautographic methods combine chromatographic separation and in situ activity determination facilitating the localization and target-directed isolation of active constituents in a mixture. Traditionally, bioautographic technique has used the growth inhibition of microorganisms to detect anti-microbial components of extracts chromatographed on a TLC layer. This methodology has been considered as the most efficacious assay for the detection of anti-microbial compounds (Shahverdi, 2007). Bio-autography localizes antimicrobial activity on a chromatogram using three approaches: (i) direct bio-autography, where the micro-organism grows directly on the thin-layer chromatographic (TLC) plate, (ii) contact bio-autography, where the antimicrobial compounds are transferred from the TLC plate to an inoculated agar plate through direct contact and (iii) agar overlay bio-autography, where a seeded agar medium is applied directly onto the TLC plate (Hamburger and Cordell, 1987; Rahalison et al., 1991). The inhibition zones produced on TLC plates by one of the above bioautographic technique will be use to visualize the position of the bioactive compound with antimicrobial activity in the TLC fingerprint with reference to $R_{f}$ values (Homans and Fuchs, 1970). Preparative TLC plates with a thickness of $1 \mathrm{~mm}$ were prepared using the same stationary and mobile phases as above, with the objective of isolating the bioactive components that exhibited the antimicrobial activity against the test strain. These areas were scraped from the plates, and the substance eluted from the silica with ethanol or methanol. Eluted samples were further purified using the above preparative chromatography method. Finally, the components were identified by HPLC, LCMS and GCMS. Although it has high sensitivity, its applicability is limited to micro-organisms that easily grow on TLC plates. Other problems are the need for complete removal of residual low volatile solvents, such as $n$ - $\mathrm{BuOH}$, trifluoroacetic acid and ammonia and the transfer of the active compounds from the stationary phase into the agar layer by diffusion (Cos et al., 2006). Because bio-autography allows localizing antimicrobial activities of an extract on the chromatogram, it supports a quick search for new antimicrobial agents through bioassay-guided isolation (Cos et al., 2006). The bioautography agar overlay method is advantageous in that, firstly it uses very little amount of sample when compared to the normal disc diffusion method and hence, it can be used for bioassay-guided isolation of compounds. Secondly, since the crude extract is resolved into its different components, this technique simplifies the process of identification and isolation of the bioactive compounds (Rahalison et al., 1991). 


\section{High performance liquid chromatography}

High performance liquid chromatography (HPLC) is a versatile, robust, and widely used technique for the isolation of natural products (Cannell, 1998). Currently, this technique is gaining popularity among various analytical techniques as the main choice for fingerprinting study for the quality control of herbal plants (Fan et al., 2006). Natural products are frequently isolated following the evaluation of a relatively crude extract in a biological assay in order to fully characterize the active entity. The biologically active entity is often present only as minor component in the extract and the resolving power of HPLC is ideally suited to the rapid processing of such multicomponent samples on both an analytical and preparative scale. Many bench top HPLC instruments now are modular in design and comprise a solvent delivery pump, a sample introduction device such as an auto-sampler or manual injection valve, an analytical column, a guard column, detector and a recorder or a printer.

Chemical separations can be accomplished using HPLC by utilizing the fact that certain compounds have different migration rates given a particular column and mobile phase. The extent or degree of separation is mostly determined by the choice of stationary phase and mobile phase. Generally the identification and separation of phytochemicals can be accomplished using isocratic system (using single unchanging mobile phase system). Gradient elution in which the proportion of organic solvent to water is altered with time may be desirable if more than one sample component is being studied and differ from each other significantly in retention under the conditions employed.

Purification of the compound of interest using HPLC is the process of separating or extracting the target compound from other (possibly structurally related) compounds or contaminants. Each compound should have a characteristic peak under certain chromatographic conditions. Depending on what needs to be separated and how closely related the samples are, the chromatographer may choose the conditions, such as the proper mobile phase, flow rate, suitable detectors and columns to get an optimum separation.

Identification of compounds by HPLC is a crucial part of any HPLC assay. In order to identify any compound by HPLC, a detector must first be selected. Once the detector is selected and is set to optimal detection settings, a separation assay must be developed. The parameters of this assay should be such that a clean peak of the known sample is observed from the chromatograph. The identifying peak should have a reasonable retention time and should be well separated from extraneous peaks at the detection levels which the assay will be performed. UV detectors are popular among all the detectors because they offer high sensitivity (Lia et al., 2004) and also because majority of naturally occurring compounds encountered have some UV absorbance at low wavelengths (190-210 nm) (Cannell, 1998). The high sensitivity of UV detection is bonus if a compound of interest is only present in small amounts within the sample. Besides UV, other detection methods are also being employed to detect phytochemicals among which is the diode array detector (DAD) coupled with mass spectrometer (MS) (Tsao and Deng, 2004). Liquid chromatography coupled with mass spectrometry (LC/MS) is also a powerful technique for the analysis of complex botanical extracts (Cai et al., 2002; He, 2000). It provides abundant information for structural elucidation of the compounds when tandem mass spectrometry $\left(\mathrm{MS}^{\mathrm{n}}\right)$ is applied. Therefore, the combination of HPLC and MS facilitates rapid and accurate identification of chemical compounds in medicinal herbs, especially when a pure standard is unavailable (Ye et al., 2007).

The processing of a crude source material to provide a sample suitable for HPLC analysis as well as the choice of solvent for sample reconstitution can have a significant bearing on the overall success of natural product isolation. The source material, e.g., dried powdered plant, will initially need to be treated in such a way as to ensure that the compound of interest is efficiently liberated into solution. In the case of dried plant material, an organic solvent (e.g., methanol, chloroform) may be used as the initial extractant and following a period of maceration, solid material is then removed by decanting off the extract by filteration. The filtrate is then concentrated and injected into HPLC for separation. The usage of guard columns is necessary in the analysis of crude extract. Many natural product materials contain significant level of strongly binding components, such as chlorophyll and other endogenous materials that may in the long term compromise the performance of analytical columns. Therefore, the guard columns will significantly protect the lifespan of the analytical columns.

\section{Non-chromatographic techniques Immunoassay}

Immunoassays, which use monoclonal antibodies against drugs and low molecular weight natural bioactive compounds, are becoming important tools in bioactive compound analyses. They show high specificity and sensitivity for receptor binding analyses, enzyme assays and qualitative as well as quantitative analytical techniques. Enzyme-linked immunosorbent essay (ELISA) based on MAbs are in many cases more sensitive than conventional HPLC methods. Monoclonal antibodies can be produced in specialized cells through a technique known as hybridoma technology (Shoyama et al., 2006). The following steps are involved in the production of monoclonal antibodies via hybridoma technology against plant drugs:

(i) A rabbit is immunized through repeated injection of specific plant drugs for the production of specific antibody, facilitated due to proliferation of the desired B cells.

(ii) Tumors are produced in a mouse or a rabbit.

(iii) From the above two types of animals, spleen cell (these cells are rich in B cells and T cells) are cultured separately. The separately cultured spleen cells produce specific antibodies against the plants drug, and against myeloma cells that produce tumors.

(iv) The production of hybridoma by fusion of spleen cells to myeloma cells is induced using polyethylene glycol (PEG). The hybrid cells are grown in selective hypoxanthine aminopterin thymidine (HAT) medium. 
(v) The desired hybridoma is selected for cloning and antibody production against a plant drug. This process is facilitated by preparing single cell colonies that will grow and can be used for screening of antibody producing hybridomas.

(vi) The selected hybridoma cells are cultured for the production of monoclonal antibodies in large quantity against the specific plants drugs.

(vii) The monoclonal antibodies are used to determine similar drugs in the plants extract mixture through enzyme-linked immunosorbent essay (ELISA).

\section{Phytochemical screening assay}

Phytochemicals are chemicals derived from plants and the term is often used to describe the large number of secondary metabolic compounds found in plants. Phytochemical screening assay is a simple, quick, and inexpensive procedure that gives the researcher a quick answer to the various types of phytochemicals in a mixture and an important tool in bioactive compound analyses. A brief summary of the experimental procedures for the various phytochemical screening methods for the secondary metabolites is shown in Table 2. After obtaining the crude extract or active fraction from plant material, phytochemical screening can be performed with the appropriate tests as shown in the Table 2 to get an idea regarding the type of phytochemicals existing in the extract mixture or fraction.

\section{Fourier-transform infrared spectroscopy (FTIR)}

FTIR has proven to be a valuable tool for the characterization and identification of compounds or functional groups (chemical bonds) present in an unknown mixture of plants extract (Eberhardt et al., 2007; Hazra et al., 2007). In addition, FTIR spectra of pure compounds are usually so unique that they are like a molecular "fingerprint". For most common plant compounds, the spectrum of an unknown compound can be identified by comparison to a library of known compounds. Samples for FTIR can be prepared in a number of ways. For liquid samples, the easiest is to place one drop of sample between two plates of sodium chloride. The drop forms a thin film between the plates. Solid samples can be milled with potassium bromide (KBr) to and then compressed into a thin pellet which can be analyzed. Otherwise, solid samples can be dissolved in a solvent such as methylene chloride, and the solution then placed onto a single salt plate. The solvent is then evaporated off, leaving a thin film of the original material on the plate.

\section{Conclusion}

Since bioactive compounds occurring in plant material consist of multi-component mixtures, their separation and determination still creates problems. Practically most of them have to be purified by the combination of several chromatographic techniques and various other purification methods to isolate bioactive compound(s). 
Table 2: A brief summary of phytochemical screening of secondary metabolites

\begin{tabular}{|c|c|c|c|c|}
\hline Secondary metabolite & Name of test & Methodology & Result(s) & Reference(s) \\
\hline \multirow[t]{4}{*}{ 1) Alkaloid } & Dragendorff's test & $\begin{array}{l}\text { Spot a drop of extract on a small piece of precoated TLC plate. Spray the plate } \\
\text { with Dragendorff's reagent. }\end{array}$ & Orange spot & (Kumar et al., 2007); \\
\hline & Wagner test & $\begin{array}{l}\text { Add } 2 \mathrm{ml} \text { filtrate with } 1 \% \mathrm{HCl}+\text { steam. Then add } 1 \mathrm{ml} \text { of the solution with } 6 \\
\text { drops of Wagner's reagent. }\end{array}$ & Brownish-red precipitate & (Chanda et al., 2006). \\
\hline & TLC method 1 & $\begin{array}{l}\text { Solvent system: Chloroform: methanol: } 25 \% \text { ammonia }(8: 2: 0.5) \text {. } \\
\text { Spots can be detected after spraying with Dragendorff reagent }\end{array}$ & Orange spot & (Tona et al., 1998) \\
\hline & TLC method 2 & $\begin{array}{l}\text { Wet the powdered test samples with a half diluted } \mathrm{NH}_{4} \mathrm{OH} \text { and lixiviated with } \\
\text { EtOAc for } 24 \mathrm{hr} \text { at room temperature. Separate the organic phase from the } \\
\text { acidified filtrate and basify with } \mathrm{NH}_{4} \mathrm{OH}(\mathrm{pH} 11-12) \text {. Then extract it with } \\
\text { chloroform (3X), condense by evaporation and use for chromatography. } \\
\text { Separate the alkaloid spots using the solvent mixture chloroform and methanol } \\
\text { (15:1). Spray the spots with Dragendorff's reagent. }\end{array}$ & Orange spot & $\begin{array}{l}\text { (Mallikharjuna et al., } \\
\text { 2007). }\end{array}$ \\
\hline \multirow[t]{2}{*}{ 2) Anthraquinone } & Borntrager's test & $\begin{array}{l}\text { Heat about } 50 \mathrm{mg} \text { of extract with } 1 \mathrm{ml} 10 \% \text { ferric chloride solution and } 1 \mathrm{ml} \text { of } \\
\text { concentrated hydrochloric acid. Cool the extract and filter. Shake the filtrate } \\
\text { with equal amount of diethyl ether. Further extract the ether extract with strong } \\
\text { ammonia. }\end{array}$ & $\begin{array}{l}\text { Pink or deep red } \\
\text { coloration of aqueous } \\
\text { layer }\end{array}$ & (Kumar et al., 2007) \\
\hline & Borntrager's test & Add $1 \mathrm{ml}$ of dilute (10\%) ammonia to $2 \mathrm{ml}$ of chloroform extract. & $\begin{array}{l}\text { A pink-red color in the } \\
\text { ammoniacal (lower) layer }\end{array}$ & (Onwukaeme et al., 2007). \\
\hline \multirow[t]{3}{*}{ 3)Cardiac glycosides } & $\begin{array}{l}\text { Kellar }- \text { Kiliani } \\
\text { test }\end{array}$ & $\begin{array}{l}\text { Add } 2 \mathrm{ml} \text { filtrate with } 1 \mathrm{ml} \text { of glacial acetic acid, } 1 \mathrm{ml} \text { ferric chloride and } 1 \mathrm{ml} \\
\text { concentrated sulphuric acid. }\end{array}$ & $\begin{array}{l}\text { Green-blue coloration of } \\
\text { solution }\end{array}$ & $\begin{array}{l}\text { (Parekh and Chanda, } \\
\text { 2007). }\end{array}$ \\
\hline & Kellar- Kiliani test & $\begin{array}{l}\text { Dissolve } 50 \mathrm{mg} \text { of methanolic extract in } 2 \mathrm{ml} \text { of chloroform. Add } \mathrm{H}_{2} \mathrm{SO} 4 \text { to } \\
\text { form a layer. }\end{array}$ & Brown ring at interphase & (Onwukaeme et al., 2007). \\
\hline & TLC method & $\begin{array}{l}\text { Extract the powdered test samples with } 70 \% \text { EtOH on rotary shaker }(180 \\
\text { thaws/min) for } 10 \mathrm{hr} \text {. Add } 70 \% \text { lead acetate to the filtrate and centrifuge at } \\
5000 \mathrm{rpm} / 10 \mathrm{~min} \text {. Further centrifuge the supernatant by adding } 6.3 \% \mathrm{Na}_{2} \mathrm{CO}_{3} \text { at } \\
10000 \mathrm{rpm} / 10 \mathrm{~min} \text {. Dry the retained supernatant and redissolved in chloroform } \\
\text { and use for chromatography. Separate the glycosides using EtOAc-MeOH- } \mathrm{H}_{2} \mathrm{O} \\
(80: 10: 10) \text { solvent mixture. }\end{array}$ & $\begin{array}{l}\text { The color and } \mathrm{hR}_{\mathrm{f}} \text { values } \\
\text { of these spots can be } \\
\text { recorded under ultraviolet } \\
\text { (UV254 nm) light }\end{array}$ & $\begin{array}{l}\text { (Mallikharjuna et al., } \\
\text { 2007). }\end{array}$ \\
\hline \multirow[t]{2}{*}{ 4) Flavonoid } & Shinoda test & $\begin{array}{l}\text { To } 2-3 \mathrm{ml} \text { of methanolic extract, add a piece of magnesium ribbon and } 1 \mathrm{ml} \text { of } \\
\text { concentrated hydrochloric acid. }\end{array}$ & $\begin{array}{l}\text { Pink red or red coloration } \\
\text { of the solution }\end{array}$ & (Kumar et al., 2007). \\
\hline & TLC method & $\begin{array}{l}\text { Extract } 1 \mathrm{~g} \text { powdered test samples with } 10 \mathrm{ml} \text { methanol on water bath }\left(60^{\circ} \mathrm{C} /\right. \\
5 \mathrm{~min}) \text {. Condense the filtrate by evaporation, and add a mixture of water and } \\
\text { EtOAc }(10: 1 \mathrm{~mL}) \text {, and mix thoroughly. Retain the EtOAc phase and use for }\end{array}$ & $\begin{array}{l}\text { The color and hRf values } \\
\text { of these spots can be } \\
\text { recorded under ultraviolet }\end{array}$ & $\begin{array}{l}\text { (Mallikharjuna et al., } \\
\text { 2007). }\end{array}$ \\
\hline
\end{tabular}




\begin{tabular}{|c|c|c|c|c|}
\hline & & $\begin{array}{l}\text { chromatography. Separate the flavonoid spots using chloroform and methanol } \\
(19: 1) \text { solvent mixture. }\end{array}$ & (UV254nm) light & \\
\hline & $\mathrm{NaOH}$ test & Treat the extract with dilute $\mathrm{NaOH}$, followed by addition of dilute $\mathrm{HCl}$. & $\begin{array}{l}\text { A yellow solution with } \\
\mathrm{NaOH} \text {, turns colorless } \\
\text { with dilute } \mathrm{HCl}\end{array}$ & (Onwukaeme et al., 2007). \\
\hline 5) Phenol & Phenol test & $\begin{array}{l}\text { Spot the extract on a filter paper. Add a drop of phoshomolybdic acid reagent } \\
\text { and expose to ammonia vapors. }\end{array}$ & Blue coloration of the spot & (Kumar et al., 2007); \\
\hline 6) Phlobatannin & - & $2 \mathrm{ml}$ extract was boiled with $2 \mathrm{ml}$ of $1 \%$ hydrochloric acid $\mathrm{HCl}$ & $\begin{array}{l}\text { Formation of red } \\
\text { precipitates }\end{array}$ & (Edeoga et al., 2005). \\
\hline 7) Pyrrolizidine alkaloid & - & $\begin{array}{l}\text { Prepare } 1 \mathrm{ml} \text { of oxidizing agent, consisting of } 0.01 \mathrm{ml} \text { hydrogen peroxide }(30 \% \\
\text { w/v) stabilized with tetrasodium pyrophosphate }(20 \mathrm{mg} / \mathrm{ml}) \text { and made up to } \\
20 \mathrm{ml} \text { with isoamylacetate, and add to } 1 \mathrm{ml} \text { of plant extract. Vortex the sample } \\
\text { and add } 0.25 \mathrm{ml} \text { acetic anhydride before heating the sample at } 60^{\circ} \mathrm{C} \text { for } 50-70 \mathrm{~s} \text {. } \\
\text { Cool the samples to room temperature. Add } 1 \mathrm{ml} \text { of Ehrlich reagent and place } \\
\text { the test tubes in water bath }\left(60^{\circ} \mathrm{C}\right) \text { for } 5 \mathrm{~min} \text {. Measure the absorbance at } \\
562 \mathrm{~nm} \text {. The method of Holstege et al. (1995) should be used to confirm results } \\
\text { of the screening method }\end{array}$ & $\begin{array}{l}\text { Peaks were compared with } \\
\text { the GC-MS library }\end{array}$ & $\begin{array}{l}\text { (McGaw et al., 2007; } \\
\text { Mattocks, 1967; Holstege et } \\
\text { al., 1995) }\end{array}$ \\
\hline 8) Reducing sugar & Fehling test & $\begin{array}{l}\text { Add } 25 \mathrm{ml} \text { of diluted sulphuric acid }\left(\mathrm{H}_{2} \mathrm{SO}_{4}\right) \text { to } 5 \mathrm{ml} \text { of water extract in a test } \\
\text { tube and boil for } 15 \mathrm{mins} \text {. Then cool it and neutralize with } 10 \% \text { sodium } \\
\text { hydroxide to } \mathrm{pH} 7 \text { and } 5 \mathrm{ml} \text { of Fehling solution. }\end{array}$ & Brick red precipitate & (Akinyemi et al., 2005) \\
\hline \multirow[t]{2}{*}{ 9) Saponin } & $\begin{array}{l}\text { Frothing test / } \\
\text { Foam test }\end{array}$ & Add $0.5 \mathrm{ml}$ of filtrate with $5 \mathrm{ml}$ of distilled water and shake well. & Persistence of frothing & $\begin{array}{l}\text { (Parekh and Chanda, } \\
\text { 2007). }\end{array}$ \\
\hline & TLC method & $\begin{array}{l}\text { Extract two grams of powdered test samples with } 10 \mathrm{ml} 70 \% \mathrm{EtOH} \text { by } \\
\text { refluxing for } 10 \mathrm{~min} \text {. Condense the filtrate, enrich with saturated } n \text {-BuOH, and } \\
\text { mix thoroughly. Retain the butanol, condense and use for chromatography. } \\
\text { Separate the saponins using chloroform, glacial acetic acid, methanol and } \\
\text { water (64:34:12:8) solvent mixture. Expose the chromatogram to the iodine } \\
\text { vapors. }\end{array}$ & $\begin{array}{l}\text { The colour (yellow) and } \\
\text { hRf values of these spots } \\
\text { were recorded by } \\
\text { exposing chromatogram to } \\
\text { the iodine vapours }\end{array}$ & $\begin{array}{l}\text { (Mallikharjuna et al., } \\
\text { 2007). }\end{array}$ \\
\hline \multirow[t]{3}{*}{ 10) Steroid } & $\begin{array}{l}\text { Liebermann- } \\
\text { Burchardt test }\end{array}$ & $\begin{array}{l}\text { To } 1 \mathrm{ml} \text { of methanolic extract, add } 1 \mathrm{ml} \text { of chloroform, } 2-3 \mathrm{ml} \text { of acetic } \\
\text { anhydride, } 1 \text { to } 2 \text { drops of concentrated sulphuric acid. }\end{array}$ & Dark green coloration & (Kumar et al., 2007). \\
\hline & - & $\begin{array}{l}\text { To } 1 \mathrm{ml} \text { of extract, add } 2 \mathrm{ml} \text { acetic anhydride and } 2 \mathrm{ml} \text { concentrated sulphuric } \\
\text { acid } \mathrm{H} 2 \mathrm{SO} 4 \text {. }\end{array}$ & $\begin{array}{l}\text { Color change to blue or } \\
\text { green }\end{array}$ & (Edeoga et al., 2005). \\
\hline & TLC method & $\begin{array}{l}\text { Extract two grams of powdered test samples with } 10 \mathrm{ml} \text { methanol in water bath } \\
\left(80^{\circ} \mathrm{C} / 15 \mathrm{~min}\right) \text {. Use the condensed filtrate for chromatography. The sterols can } \\
\text { be separated using chloroform, glacial acetic acid, methanol and water } \\
(64: 34: 12: 8) \text { solvent mixture. The color and hRf values of these spots can be } \\
\text { recorded under visible light after spraying the plates with anisaldehyde- } \\
\text { sulphuric acid reagent and heating }\left(100^{\circ} \mathrm{C} / 6 \mathrm{~min}\right)\end{array}$ & $\begin{array}{l}\text { The color (Greenish black } \\
\text { to Pinkish black) and } \mathrm{hR}_{\mathrm{f}} \\
\text { values of these spots can } \\
\text { be recorded under visible } \\
\text { light }\end{array}$ & $\begin{array}{l}\text { (Mallikharjuna et al., } \\
\text { 2007). }\end{array}$ \\
\hline
\end{tabular}




\begin{tabular}{|c|c|c|c|c|}
\hline 11) Tannin & Braemer's test & $\begin{array}{l}10 \% \text { alcoholic ferric chloride will be added to } 2-3 \mathrm{ml} \text { of methanolic extract } \\
(1: 1)\end{array}$ & $\begin{array}{l}\text { Dark blue or greenish grey } \\
\text { coloration of the solution }\end{array}$ & $\begin{array}{l}\text { (Kumar et al., 2007); } \\
\text { (Parekh and Chanda, } \\
\text { 2007). }\end{array}$ \\
\hline \multirow[t]{2}{*}{ 12) Terpenoid } & $\begin{array}{l}\text { Liebermann- } \\
\text { Burchardt test }\end{array}$ & $\begin{array}{l}\text { To } 1 \mathrm{ml} \text { of methanolic extract, add } 1 \mathrm{ml} \text { of chloroform, } 2-3 \mathrm{ml} \text { of acetic } \\
\text { anhydride, } 1 \text { to } 2 \text { drops of concentrated sulphuric acid. }\end{array}$ & Pink or red coloration & (Kumar et al., 2007). \\
\hline & Salkowski test & $\begin{array}{l}5 \mathrm{ml} \text { extract was added with } 2 \mathrm{ml} \text { of chloroform and } 3 \mathrm{ml} \text { of concentrated } \\
\text { sulphuric acid } \mathrm{H} 2 \mathrm{SO} 4 \text {. }\end{array}$ & $\begin{array}{l}\text { Reddish brown color of } \\
\text { interface }\end{array}$ & (Edeoga et al., 2005). \\
\hline 13) Volatile oil & - & $\begin{array}{l}\text { Add } 2 \mathrm{ml} \text { extract with } 0.1 \mathrm{ml} \text { dilute } \mathrm{NaOH} \text { and small quantity of dilute } \mathrm{HCl} \text {. } \\
\text { Shake the solution. }\end{array}$ & $\begin{array}{l}\text { Formation of white } \\
\text { precipitates }\end{array}$ & (Dahiru et al., 2006). \\
\hline
\end{tabular}




\section{References}

1. Akinyemi, K.O., Oladapo, O., Okwara, C.E., Ibe, C.C. and Fasure, K.A. (2005). Screening of crude extracts of six medicinal plants used in South-West Nigerian unorthodox medicine for anti-methicilin resistant Staphylococcus aureus activity. BMC Complement. Altern. Med. 5: 6.

2. Cai, Z., Lee, F.S.C., Wang, X.R. and Yu, W.J. (2002). A capsule review of recent studies on the application of mass spectrometry in the analysis of Chinese medicinal herbs. J. Mass Spectrom. 37: 1013-1024.

3. Cannell, R.J.P. (1998). Natural Products Isolation. Human Press Inc. New Jersey, pp. 165-208.

4. Chanda, S.V., Parekh, J. and Karathia, N. (2006). Evaluation of antibacterial activity and phytochemical analysis of Bauhinia variegate L. bark. Afr. J. Biomed. Res. 9: 53-56.

5. Cosa, P., Vlietinck, A.J., Berghe, D.V., Maes, L. (2006). Anti-infective potential of natural products: How to develop a stronger in vitro 'proof-of-concept'. J. Ethnopharmacol. 106: 290-302.

6. Cunha, I.B.S., Sawaya, A.C.H.F., Caetano, F.M., Shimizu, M.T., Marcucci, M.C., Drezza, F.T., Povia, G.S. and Carvalho, P.O. (2004). Factors that influence the yield and composition of Brazilian propolis extracts. J. Braz. Chem. Soc. 15: 964-970.

7. Dahiru, D., Onubiyi, J.A. and Umaru, H.A. (2006). Phytochemical screening and antiulcerogenic effect of Mornigo oleifera aqueous leaf extract. Afr. J. Trad. CAM 3: 70-75.

8. Duraipandiyan, V., Ayyanar, M. and Ignacimuthu, S. (2006). Antimicrobial activity of some ethnomedicinal plants used by Paliyar tribe from Tamil Nadu, India. BMC Complementary Altern. Med. 6: 35-41.

9. Eberhardt, T.L., Li, X., Shupe, T.F. and Hse, C.Y. (2007). Chinese Tallow Tree (Sapium Sebiferum) utilization: Characterization of extractives and cell-wall chemistry. Wood Fiber Sci. 39: 319-324.

10. Edeoga, H.O., Okwu, D.E. and Mbaebie, B.O. (2005). Phytochemical constituents of some Nigerian medicinal plants. Afr.J. Biotechnol. 4: 685-688.

11. Fabricant, D.S. and Farnsworth, N.R. (2001). The value of plants used in traditional medicine for drug discovery. Environ. Health Perspect. 109, 69-75.

12. Fan, X.H., Cheng, Y.Y., Ye, Z.L., Lin, R.C. and Qian, Z.Z. (2006). Multiple chromatographic fingerprinting and its application to the quality control of herbal medicines. Anal. Chim. Acta 555: 217-224.

13. Hamburger, M.O. and Cordell, G.A. (1987). A direct bioautographic TLC assay for compounds possessing antibacterial activity. J. Nat. Prod. 50: 19-22.

14. Hazra, K. M., Roy R. N., Sen S. K. and Laska, S. (2007). Isolation of antibacterial pentahydroxy flavones from the seeds of Mimusops elengi Linn. Afr. J. Biotechnol. 6 (12): 1446-1449.

15. He, X.G. (2000). On-line identification of phytochemical constituents in botanical extracts by combined high-performance liquid chromatographic-diode array detection mass spectrometric techniques. J. Chromatogr. A 880: 203-232.

16. Holstege, D.M., Seiber, J.N. and Galey, F.D. (1995). Rapid multiresidue screen for alkaloids in plant material and biological samples. J. Agric. Food Chem. 43: 691-699.

17. Homans, A.L. and Fuchs, A. (1970). Direct bioautography on thin-layer chromatograms as a method for detecting fungitoxic substances. J. Chromatogr. 51: 327-329.

18. Huie, C.W. (2002). A review of modern sample-preparation techniques for the extraction and analysis of medicinal plants. Anal. Bioanal. Chem. 373: 23-30.

19. Kumar, G.S., Jayaveera, K.N., Kumar, C.K.A., Sanjay, U.P., Swamy, B.M.V. and Kumar, D.V.K. (2007). Antimicrobial effects of Indian medicinal plants against acne-inducing bacteria. Trop. J. Pharm. Res. 6: 717723.

20. Li, H.B., Jiang, Y. and Chen, F. (2004). Separation methods used for Scutellaria baicalensis active components . J. Chromatogr. B. 812: 277-290.

21. Mallikharjuna, P.B., Rajanna, L.N., Seetharam, Y.N. and Sharanabasappa, G.K. (2007). Phytochemical studies of Strychnos potatorum L.f.- A medicinal plant. E-J. Chem. 4: 510 -518.

22. Mattocks, A.R. (1967). Spectrophotometric determination of unsaturated pyrrolizidine alkaloids. Anal. Chem. 39: 443-447.

23. McGaw, L.J., Steenkamp, V. and Eloff, J.N. (2007). Evaluation of Athrixia bush tea for cytotoxicity, antioxidant activity, caffeine content and presence of pyrolizidine alkaloids. J. Ethnopharmacol. 110: 16-22.

24. Onwukaeme, D.N., Ikuegbvweha, T.B. and Asonye, C.C. (2007). Evaluation of phytochemical constituents, antibacterial activities and effect of exudates of Pycanthus angolensis Weld Warb (Myristicaceae) on corneal ulcers in rabbits. Trop. J. Pharm. Res. 6: 725-730.

25. Parekh, J. and Chanda, S.V. (2007). In vitro antimicrobial activity and phytochemical analysis of some Indian medicinal plants. Turk. J. Biol. 31: 53-58.

26. Pharmacopoeia of the People's Republic of China, (2000). English ed., The Pharmacopeia Commission of PRC, Beijing.

27. Phrompittayarat, W., Putalun, W., Tanaka, H., Jetiyanon, K., Wittaya-areekul, S. and Ingkaninan, K. (2007). Comparison of various extraction methods of Bacopa monnier. Naresuan Univ. J. 15(1): 29-34. 
28. Rahalison, L., Hamburger, M., Hostettmann, K., Monod, M. and Frenk, E. (1991). A bioautographic agar overlay method for the detection of antifungal compounds from higher plants. Phytochem. Anal. 2: 199-203.

29. Sasidharan, S. Darah, I. and Jain K. (2008). In Vivo and In Vitro toxicity study of Gracilaria changii. Pharm. Biol. 46: 413-417.

30. Shahverdi, A.R., Abdolpour, F., Monsef-Esfahani, H.R. and Farsam, H.A. (2007). TLC bioautographic assay for the detection of nitrofurantoin resistance reversal compound. J. Chromatogr. B 850: 528-530.

31. Shoyama, Y., Tanaka, H. and Fukuda, N. (2003). Monoclonal antibodies against naturally occurring bioactive compounds. Cytotechnology 31: 9-27.

32. The Japanese Pharmacopeia, (2001). Fourteenth ed., JP XIII, The Society of Japanese Pharmacopeia, Japan.

33. Tona, L., Kambu, K., Ngimbi, N., Cimanga, K. and Vlitinck, A.J. (1998). Antiamoebic and phytochemical screening of some Congolese medicinal plants. J. Ethnopharmacol. 61: 57-65.

34. Tsao, R. and Deng, Z. (2004). Separation procedures for naturally occurring antioxidant phytochemicals. J. Chromatogr. B 812: 85-99.

35. United States Pharmacopeia and National Formulary, USP 25, NF 19, (2002). United States Pharmacopeial Convention Inc., Rockville.

36. Woisky, R.G. and Salatino, A. (1998). Analysis of propolis: some parameters and procedures for chemical quality control. J. Apicult. Res. 37: 99-105.

37. Ye, M., Han, J., Chen, H., Zheng, J. and Guo, D. (2007). Analysis of phenolic compounds in rhubarbs using liquid chromatography coupled with electrospray ionization mass spectrometry. J. Am. Soc. Mass Spectrom. 18: 82-91.

38. Zygmunt, J.B. and Namiesnik, J. (2003). Preparation of samples of plant material for chromatographic analysis. J. Chromatogr. Sci. 41: 109-116. 